\title{
Surface and deep water changes in the subpolar North Atlantic during Termination II and the last interglaciation
}

\author{
Henning A. Bauch,1 Helmut Erlenkeuser, 2 Simon J. A. Jung, 3 and Jörn Thiede4
}

\begin{abstract}
To reconstruct the history of water mass exchange between the NE Atlantic and the Nordic seas, sediment cores from $-2 \mathrm{~km}$ water depth were studied across Termination II (TII) and through the last interglaciation (MIS5e). During early TII the sudden appearance of the low-latitude planktonic foraminifera Beella megastoma is noted in both regions along with a steep decrease in benthic foraminiferal $\delta 180$. Since other proxies indicate that surface waters were cold and stratified because of meltwater, conditions which prevented near-surface thermohaline circulation and vertical convection in the Nordic seas, water mass exchange between the two areas occurred at the subsurface. During later TII, surface conditions changed, and this subsurface circulation style was eventually replaced by vertical convection. In the Nordic seas, $B$. megastoma vanished from the record together with ice-rafted debris (IRD) at the end of TII, while subpolar foraminiferal abundance rose. Peak interglacial conditions with intensive vertical convection now fully developed, generating a bottom water temperature gradient of $\sim 4^{\circ} \mathrm{C}$ between the two areas. However, surface water temperatures deteriorated in the Nordic seas already notably before IRD recurred, and $\delta^{18} \mathrm{O}$ increased at the end of MIS5e.
\end{abstract}

\section{Introduction}

For the northernmost Atlantic (Nordic seas) it is generally believed that the process of vertical overturning of surface waters to contribute to the formation of North Atlantic Deep Water (NADW) was strongly reduced during glacial periods [Duplessy et al., 1991; Sarnthein et al., 1994] and that this process remained in a transient and unstable mode during the last climate transition [Lehman and Keigwin, 1992]. Subtle variations in surface water salinity in this area of water mass overturning are, therefore, thought to account for some of the climatic changes observed in marine records during major climate transitions [Broecker and Denton, 1989; Rahmstorf, 1995].

When comparing the last two glacial-interglacial transitions, Terminations I and II (TI and TII), some discrepancies have been pointed out for TIl in terms of solar forcing [Ruddiman et al., 1980; Crowley and Kim, 1994] as well as in the timing of the response between the Southern and Northern Atlantic Ocean [Broecker and Henderson, 1998]. However, using stable isotope records from the North Atlantic, there is little evidence for major differences in the behavior of the ocean [e.g., Sarnthein and Tiedemann, 1990; Oppo et al., 1997]. In contrast, significant differences between the two climate transitions are found in sedimentologic, isotopic and micropaleontologic records from high-northern latitudes [Stoner et al., 1995; Bauch et al., 1996, 1999]. Some faunal data from the Nordic seas are particularly unusual, revealing the occurrence of the low-latitude planktonic foraminifer Beella megastoma ("Beella event") during Termination II

'GEOMAR Research Center for Marine Geosciences, Kiel, Germany.

${ }^{2}$ Leibniz Laboratory, Kiel University, Kiel, Germany.

${ }^{3}$ Institute of Earth Sciences, Amsterdam Free University, Amsterdam.

'Alfred Wegener Institute for Polar and Marine Research, Bremerhaven, Germany.

Copyright 2000 by the American Geophysical Union.

Paper number 1998PA000343.

0883-8305/00/1998PA000343\$12.00
[Bauch, 1994, 1996]. This Beella event seems confined to the deglacial interval and did not persist into the later period when interglacial conditions were fully established, i.e., when IRD finally vanished from the records as well as when warm Atlantic waters became advected at the surface and transformed into deep waters concurrent with an increasingly rising proportion of warm water indicating, subpolar foraminifera [Bauch et al., 1996].

To better understand the mechanisms behind the oceanic processes during TII and the last interglaciation, marine isotopic stage 5e (MIS5e), we will look at a series of characteristic deep and surface water records obtained from cores in the NE Atlantic and the Nordic seas. Using several prominent events from these records, a detailed stratigraphic correlation scheme will be established which allows for the reconstruction of the history of deep and surface water mass circulation between the two areas.

\section{Oceanography, Material, and Methods}

\subsection{Regional Oceanography and Core Sites}

The modern hydrographic contrasts in surface water properties of the Nordic seas result from the advection of relatively warm and saline North Atlantic surface water from the southeast and the flow of comparatively cooler and lower salinity polar water along the east Greenland continental margin southward [Swift, 1986]. Cooling processes are instrumental for the vertical overturn of these surface waters to form dense and cold waters in the Iceland and Greenland seas; this water contributes to the world ocean's circulation system by overflowing the Greenland-Scotland Ridge into the North Atlantic [Aagaard and Carmack, 1994].

We selected core M23352 (water depth $1819 \mathrm{~m}$, bottom temperature $-0.9^{\circ} \mathrm{C}$ ) from the northern Iceland Plateau (Figure 1) as it contains a well defined record of TII and the associated Beella event [Bauch, 1996]. Although today located close to the Polar Front, this site became strongly influenced by Atlantic surface water during MIS5e [ Bauch et al., 1999]. Our reference core M23414 from the Rockall 


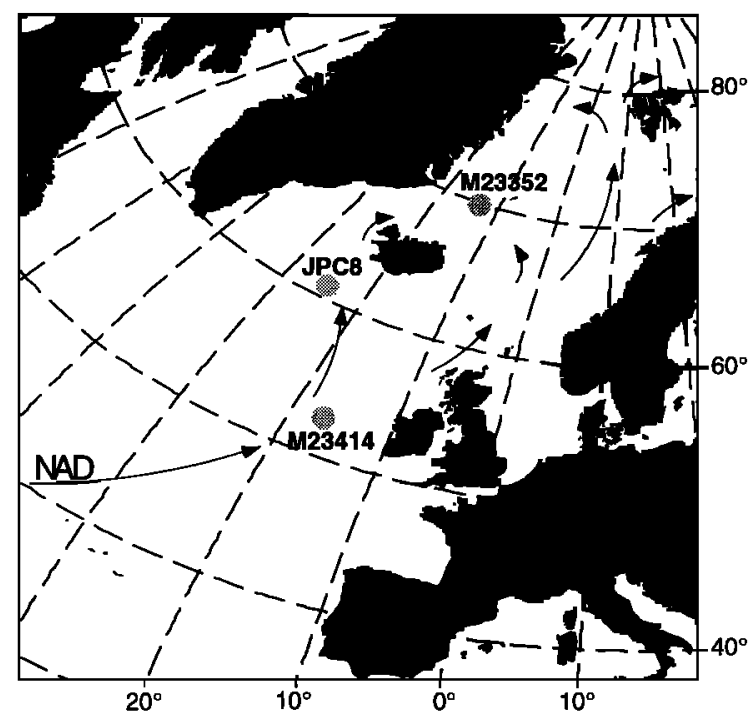

Figure 1. Geographical positions of investigated cores M23352 from the NW Iceland Plateau $\left(70^{\circ} 00.4^{\prime} \mathrm{N}, 1^{\circ} 25.8^{\prime} \mathrm{W}\right.$, water depth $\left.1819 \mathrm{~m}\right)$ and M23414 from the Rockall Plateau $\left(53^{\circ} 32.2^{\prime} \mathrm{N}, 20^{\circ} 17.3^{\prime} \mathrm{W}\right.$, water depth $2196 \mathrm{~m}$ ). Data of these cores are compared with records of core JPC8 $\left(61^{\circ} \mathrm{N}, 25^{\circ} \mathrm{W}\right.$, water depth $\left.1917 \mathrm{~m}\right)$ from the Iceland Basin [Oppo et al., 1997]. Arrows indicate the general pathway of surface water circulation along the North Atlantic Drift (NAD).

Plateau in the NE Atlantic (water depth $2196 \mathrm{~m}$, bottom temperature $3.2^{\circ} \mathrm{C}$ ) directly underlies the North Atlantic Drift. Data of the two cores will be compared with records from core JPC8 [Oppo et al., 1997] from south of Iceland (water depth $1917 \mathrm{~m})$.

\subsection{Sampling and Counting Technique}

Samples of M23352 were taken as $1 \mathrm{~cm}$ thick slices $(\geq 25$ $\mathrm{cm}^{3}$ yielding 10-30 $\mathrm{g}$ of dry sediment) at close intervals: each centimeter during the Beella event and at $-2 \mathrm{~cm}$ steps below and above. Radiographs from the glacial and deglacial core sections did not reveal obvious bioturbation. Sampling of M23414 was carried out at $2.5 \mathrm{~cm}$ intervals using $10 \mathrm{ml}$ syringes.

Counting $B$. megastoma was performed in both cores on the section covering MIS5e, and in core M23414 also on the Holocene interval. Because of its generally low abundance and to avoid statistical errors arising from down-splitting samples, the entire unsplit sample fraction $>250 \mu \mathrm{m}$ was used [Bauch, 1994]. Up to 200 tests were found per sample (equal to $\sim 3 \%$ of the total fauna in this mesh size). All other faunal counts were carried out $>125 \mu \mathrm{m}$ mesh size, following the procedure described by Bauch [1996].

Ice-rafted debris (IRD) was counted in the mesh size $>250$ $\mu \mathrm{m}$. For stratigraphic purposes the sediment reflectance was measured on core M23414 at discrete $1 \mathrm{~cm}$ intervals using a Minolta cm-2002 which calculates the gray level (\%) for the range $400-700 \mathrm{~nm}$.

\subsection{Stable Isotope Analyses}

The benthic species Cibicidoides wuellerstorfi is widely used for stable isotope analyses because of its epifaunal habitat and its reliable recording of stable carbon isotopes. In the Nordic seas this species has a low abundance record in glacial and deglacial sediments [Belanger, 1982], and $\delta^{18} \mathrm{O}$ records of $C$. wuellerstorfi were previously spliced together with $\delta^{18} \mathrm{O}$ data obtained from the infaunal species Oridorsalis umbonatus conformis tener [Labeyrie et al., 1987; Bauch et al., 1996]. However, in this study $C$. wuellerstorfi and $O$. umbonatus are used independently after correcting their $\delta^{18} \mathrm{O}$ values by $+0.64 \%$ and $+0.36 \%$, respectively, to account for their well known species-dependent departures from isotopic equilibrium [Duplessy et al., 1988].

Stable isotopes were measured using a Finnigan MAT 251 mass spectrometer linked to an automated carbonate preparation device with individual acid reaction chambers. The analytical accuracy of this system is $\pm 0.07 \%$ for $\delta^{18} \mathrm{O}$ and $\pm 0.04 \%$ o for $\delta^{13} \mathrm{C}$ (NBS-19), and results were calibrated to Pee Dee Belemnite (PDB). All isotope analyses from M23352 were carried out on multiple-specimen samples from different size classes: 28 four-chambered specimens of the polar species Neogloboquadrina pachyderma sinistral from the $125-250 \mu \mathrm{m}$ size fraction, 15 specimens of $B$ megastoma (250$500 \mu \mathrm{m}$ size fraction), an average 20 specimens of $O$. umbonatus ( $125-250 \mu \mathrm{m}$ size fraction), 5 specimens of $C$. wuellerstorfi $(250-500 \mu \mathrm{m}$ size fraction) from the deglacial and interglacial, and 1-5 specimens from the glacial core section.

Using the oxygen stratigraphy of Martinson et al. [1987], the average sedimentation rate across MIS5e (calculated between the tie-points substage 6.2 and 5.4 ) is $-4 \mathrm{~cm} / \mathrm{ky}$ for core M23414 and $\sim 2 \mathrm{~cm} / \mathrm{ky}$ for core M23352.

\section{Results}

\subsection{Records From the Iceland Plateau}

On the planktonic $\delta^{18} \mathrm{O}$ records the interval of MIS5e in core M23352 is recognized to be between 212 and $270 \mathrm{~cm}$ core depth (Figure $2 a$ )! This is also confirmed by faunal proxy data, e.g., the occurrence of Pullenia bulloides in MIS5a [Bauch et al., 1999]. The postglacial decrease in the $\delta^{180}$ records of $N$. pachyderma sinistral and $O$. umbonatus above the maximum values in late MIS6 is $-0.4 \%$ (between 260 and $252 \mathrm{~cm}$ ). For the same interval the $\delta^{18} \mathrm{O}$ change in $C$ wuellerstorfi is $1.3 \%$, which goes along with a steep decrease in $\delta^{13} \mathrm{C}$. Despite unchanged deposition of IRD, coincident with the low anomalies in the isotopes of $C$. wuellerstorfi at $-252 \mathrm{~cm}$, there is the sudden appearance of the planktonic foraminifera $B$. megastoma (Figure 2e); together with this first appearance of $B$. megastoma we have also noted an increase in test abundance of $C$. wuellerstorfi. Above $252 \mathrm{~cm}$ the planktonic and the benthic $\delta^{18} \mathrm{O}$ records ( $O$. umbonatus) steadily decrease, and lowest values are found between 247 and $244 \mathrm{~cm}$ together with high deposition of IRD. While the $\delta^{18} \mathrm{O}$ records of $N$. pachyderma sinistral and $O$. umbonatus, decrease the $\delta^{13} \mathrm{C}$ and $\delta^{18} \mathrm{O}$ values in $C$. wuellerstorfi are increasing for the same depth interval. This difference in $\delta^{18} \mathrm{O}$ between the two benthic records disappears after $246 \mathrm{~cm}$.

\footnotetext{
${ }^{1}$ Supporting data for Figures 2-5 are available on diskette or via Anonymous FTP from kosmos.agu.org, directory APEND (Username=anonymous, Password=guest). Diskette may be ordered from American Geophysical Union, 2000 Florida Avenue, N.W. Washington, DC 20009 or by Phone at $800-966-2481 ; \$ 15.00$. Payment must accompany order.
} 


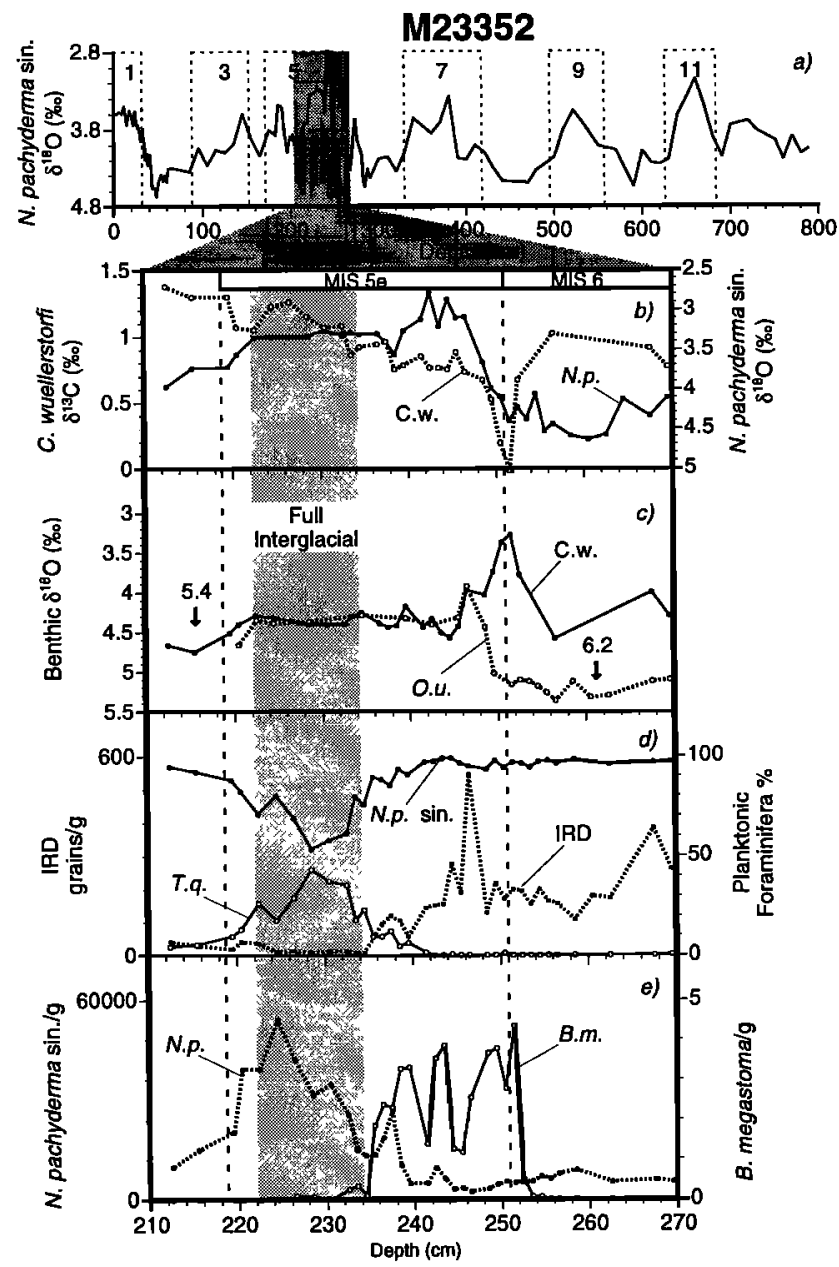

Figure 2. Down-core records of M23352 from the NW Iceland Plateau. The long stratigraphic $\delta^{18} \mathrm{O}$ record showing the oxygen isotope stages is based on Neogloboquadrina pachyderma sinistral (Figure 2a), data partly taken from Henrich [1998]. Inset below shows detailed records across the last interglaciation. The shaded area in the inset marks the interval when full interglacial conditions prevailed in this area, i.e., stable benthic and planktonic $\delta^{18} \mathrm{O}$ values, strong decrease in polar foraminiferal abundance (percent of $N$. pachyderma sinistral), and lowest concentration of ice-rafted detritus (IRD). In contrast, Beella megastoma occurred during times of intense IRD deposition, decreasing $\delta^{18} \mathrm{O}$ values but high relative abundance of $N$. pachyderma sinistral. Note that the dominant subpolar foraminifer Turborotalita quinqueloba (T.q.) began to decrease within full interglacial times, indicating that surface conditions toward the end of MIS5e cooled well before ice sheet growth is documented by IRD and $\delta^{18} \mathrm{O}$.

Above $\sim 242 \mathrm{~cm}$ the planktonic $\delta^{18} \mathrm{O}$ record increases, while IRD content and the relative abundance of $N$. pachyderma sinistral start to decline (Figure 2e). However, the subpolar species Turborotalita quinqueloba increased significantly only after IRD and $B$. megastoma vanished from the record. The ensuing IRD-free section is characterized by high proportions of subpolar species and relatively constant benthic as well as planktonic $\delta^{18} \mathrm{O}$ values, thus indicating the change toward full interglacial conditions in this area. These stable conditions persisted until $\sim 222 \mathrm{~cm}$, when all three $\delta^{18} \mathrm{O}$ records exhibit a coeval increase, heralding the known global cooling and change in ice volume toward MIS 5.4. Although this $\delta^{18} \mathrm{O}$ increase is associated with a renewed deposition in IRD shortly after, subpolar abundance already decreased above $228 \mathrm{~cm}$ (Figure 2d).

\subsection{Records From the NE Atlantic}

At the Rockall Plateau site, records of planktonic and benthic $\delta^{18} \mathrm{O}$ as well as of the sediment reflectance in core M23414 (Figure 3) are very similar to nearby cores [Labeyrie et al., 1995; Cortijo et al., 1995], allowing for a robust stratigraphic framework. Here $B$. megastoma occurs in the Holocene and in MIS5e. High IRD at the end of the last two major glaciations (MIS6 and 2) is consistent with previous studies, which showed increased IRD deposition caused by extensive iceberg discharge during these times [Ruddiman and McIntyre, 1981; McManus et al., 1994].

Although a comparison of the planktonic and benthic $\delta^{18} \mathrm{O}$ records reveals an overall good correspondence for the MIS5e interval $(-480-387 \mathrm{~cm})$, the onset of deglaciation at the southern Rockall Plateau is marked by a significant lag in the planktonic $\delta^{18} \mathrm{O}$ decrease relative to the benthic decrease. Above $430 \mathrm{~cm}$ depth, the major difference between the two records is the greater amplitude of planktonic $\delta 180$ oscillations, presumably caused by a greater effect of temperature and/or meltwater on the planktonic isotope values. The data suggest that full interglacial conditions were reached after $\sim 420 \mathrm{~cm}$ depth when (1) IRD disappeared, (2) the lightest values in gray reflectance indicate high carbonate content, and (3) the lowest benthic $\delta^{18} \mathrm{O}$ values occurred; the light spike seen at $402 \mathrm{~cm}$ is ignored because it is not recorded elsewhere in this region [Cortijo et al., 1994; Oppo and Lehman, 1995].

As on the Iceland Plateau, the upper deglacial section in M23414 with IRD has slightly lower planktonic $\delta^{18} \mathrm{O}$ values than noted for the later part of MIS5e with no IRD. A very similar trend is seen in $\delta^{18} \mathrm{O}$ and surface salinity data from nearby core SU 90-39 [Labeyrie et al., 1995], which indicate a significant influence of freshwater during the first part of MIS5e. Another agreement of core M23414 with the Iceland Plateau records is the prominent depletion in benthic $\delta^{13} \mathrm{C}$ during early TII and near the end of MIS5e when benthic and planktonic $\delta^{18} \mathrm{O}$ steeply increase toward MIS 5.4.

In Figures $3 \mathrm{e}$ and $3 \mathrm{f}$ some key species are shown which are known to reflect progressively cooler surface water conditions in the North Atlantic [Bé and Tolderlund, 1971; Kipp, 1976, Kellogg, 1984; Bauch, 1994; Johannessen et al., 1994]. All these subtropical to subpolar species increase in number near 440-430 cm depth. However, there are some important differences in their relative proportions. Whereas the two subtropical-temperate species $B$. megastoma and $G$. truncatulinoides reach their highest concentrations during the first half of MIS5e $(-420-410 \mathrm{~cm})$, the abundance of the "colder", temperate-subpolar species $G$. inflata remains at a high level throughout MIS5e and is similar to the pattern seen in the sediment reflectance. In contrast, the increase of the subpolar species T. quinqueloba and $G$. bulloides relative to the others occurred only after MIS5e, presumably, when the surface water temperatures became more cold and unstable again in the NE Atlantic [e.g., Labeyrie et al., 1995; Oppo and Lehman, 1995]. It is noteworthy that during TI and the Holocene the faunal pattern of these species departs significantly from what 


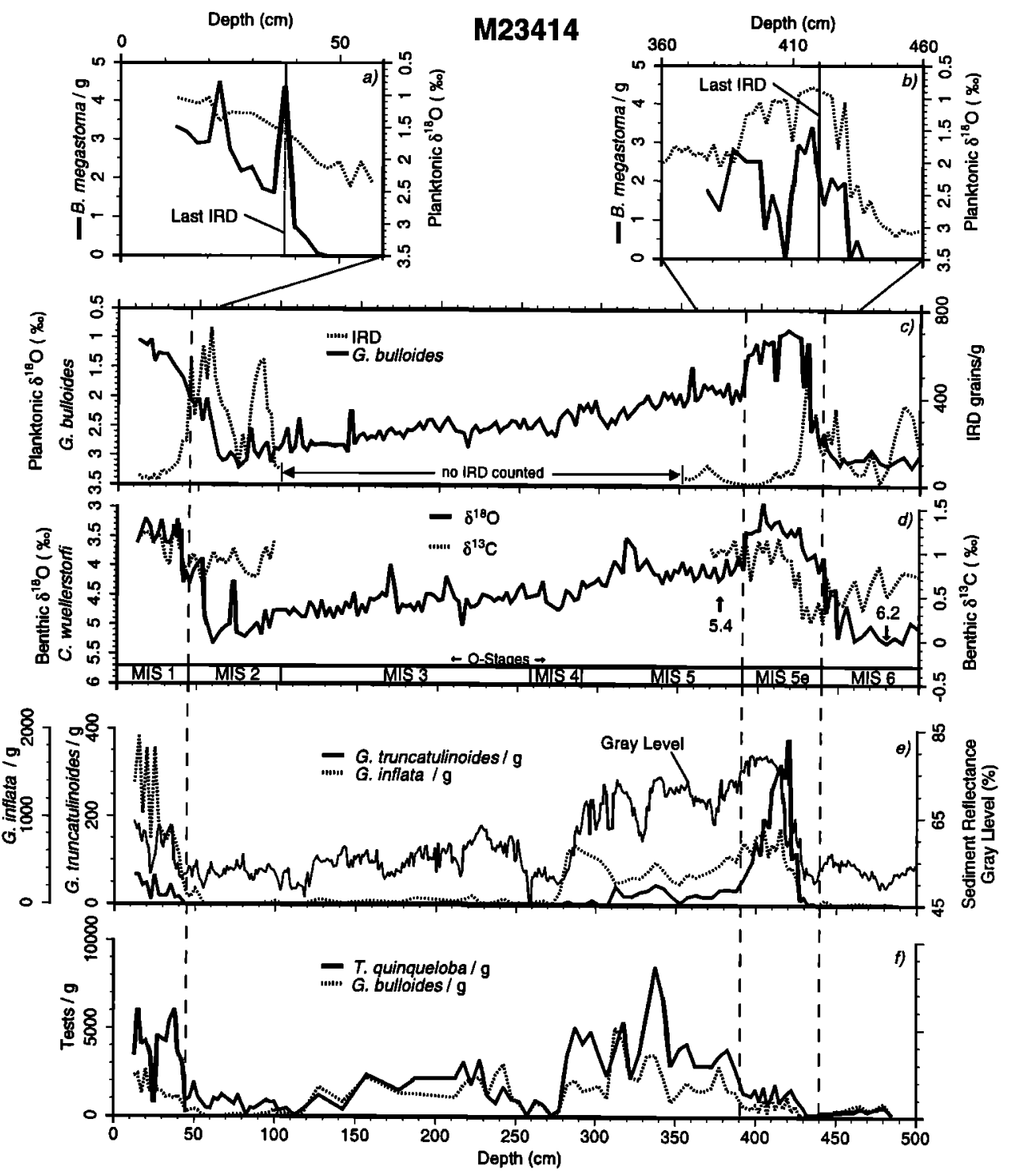

Figure 3. Faunal, sedimentologic, and isotopic downcore records of M23414-9 from the Rockall Plateau since MIS6 (Figures 3c-3f). The two insets at the top (Figures $3 \mathrm{a}$ and $3 \mathrm{~b}$ ) document that in the North Atlantic, in contrast to the Nordic seas, Beella megastoma persisted throughout MIS5e and MISl.

is recorded in TII and MIS5e. This may be related to the general lack of a Beella event in the Nordic seas during TI [Bauch, 1996].

\subsection{Comparison of Planktonic $\mathbf{8}^{18} \mathbf{O}$}

The widespread appearance of $B$. megastoma in many Nordic seas sediment cores as far north as $76^{\circ}$ latitude [Bauch, 1996], when other faunal proxies still suggest polar surface conditions, indicates that its occurrence was not a short-lived event of surface water advection from the south. Today, this species lives within the subtropical to temperate water masses of the North Atlantic outside subpolar conditions. Although no plankton tow data are available for this species that could give definite information on its main depth habitat, it has been reported to occur at greater depths in the Mediterranean [Hemleben et al., 1989]. The $\delta^{18} \mathrm{O}$ is used here to shed more light onto the ecology of $B$. megastoma. Comparison of the Holocene $\delta^{18} \mathrm{O}$ signature in $N$. pachyderma sinistral and $B$. megastoma reveals a distinct offset averaging $1.25 \%$ (Figure 4). This offset might be caused, among many other factors, by a different depth habitat and/or vital effect. Assuming that the $1.25 \%$ difference between the two species is applicable to MIS5e, the two $\delta^{18} \mathrm{O}$ records from the Iceland Plateau show similar general trends (Figure 5), particularly above $242 \mathrm{~cm}$ when both IRD and relative abundance of $N$. pachyderma sinistral decrease. This similar trend suggests that both species were recording the same changes in surface water properties (Figures $2 \mathrm{~d}$ and $2 \mathrm{e}$ ). Taking the uppermost three data points of $B$. megastoma at face value would imply, however, that this species now lived at greater depth than $N$. pachyderma sinistral. Although for $N$. pachyderma sinistral a relatively deep main calcification depth is usually cited [Hemleben et al., 1989], this depth may vary significantly in 


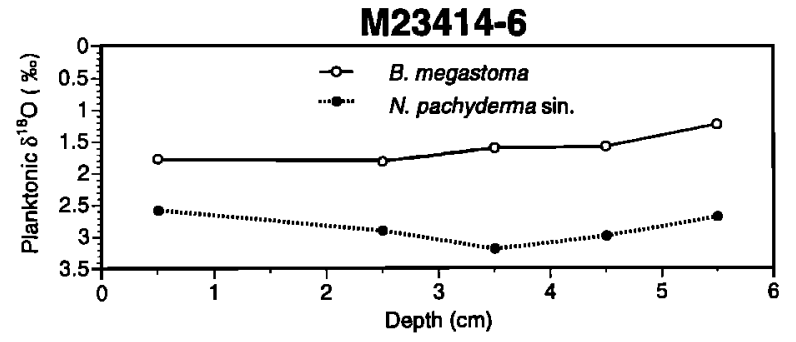

Figure 4. The $\delta^{18} \mathrm{O}$ records of Beella megastoma and Neogloboquadrina pachyderma sinistral from the upper $6 \mathrm{~cm}$ of a trigger box core taken at site $\mathrm{M} 23414\left(53^{\circ} 32.2^{\prime} \mathrm{N}, 20^{\circ} 17.4^{\prime} \mathrm{W}\right.$, water depth $2201 \mathrm{~m})$ in the NE Atlantic. The $\Delta \delta^{18} \mathrm{O}$ of the two species averages $1.25 \%$.

ice-covered polar regions where stratified surface waters occur [Bauch et al., 1997].

\section{Paleoceanographic Implications}

\subsection{Event Stratigraphy}

To reconstruct the water mass history between the two sites, a correlation scheme was established (Figure 6). The lowermost correlation line (line $A$ ) is drawn at the first occurrence of $B$. megastoma, which falls together with marked changes in the $\delta^{13} \mathrm{C}$ and $\delta^{18} \mathrm{O}$ records. The same works fairly well for the upper correlation line (line D). Using this good agreement between the two records, there is little doubt that both sites experienced relatively rapid water mass exchanges. However, if our other correlation lines (lines B and C) are correct, then the disappearance of IRD in the NE Atlantic and on the Iceland Plateau during TII was diachronous, as was its reappearance after MIS5e.

\subsection{Termination II}

To explain the considerable amounts of IRD at the Iceland Plateau site during TII as Heinrich-like events would require enhanced iceberg calfing due to cooling [Bond et al., 1992; McManus et al., 1994]. However, the presence of IRD grains throughout this core section also implies that icebergs were actually melting and generating cold and fresh surface waters. This freshwater seems to be recorded by $N$. pachyderma sinistral as well as by $B$. megastoma with low $\delta^{18} \mathrm{O}$ values (Figure 5). Today, N. pachyderma sinistral records comparatively heavy $\delta^{18} \mathrm{O}$ values $(-3.5 \%$ ) along east Greenland [e.g., Sarnthein et al., 1995] (see also Figure 2a) despite substantial melting of sea ice and icebergs causing both stratification and freshening of the upper surface waters. However, the halocline in this area remains relatively thin compared with the $200-300 \mathrm{~m}$ thick layer observed in the Arctic Ocean where the $\delta^{18} \mathrm{O}$ signature of $N$. pachyderma sinistral is found to be significantly influenced by freshwater [Spielhagen and Erlenkeuser, 1994; Bauch et al., 1997]. The increasing trend in both planktonic $\delta^{18} \mathrm{O}$ records after $242 \mathrm{~cm}$ (Figure 5) may partially be the consequence of a decreasing meltwater supply toward the end of TII, i.e., increasing surface salinities. This is corroborated by a first increase in $T$. quinqueloba abundance during this interval, a symbiontbearing, shallow-living species which seems to avoid low salinities in the Nordic seas [Carstens, 1991; Carstens et al., 1997]. Therefore, we conclude that the extreme "overshoot" in $\delta^{18} \mathrm{O}$ recorded by $N$. pachyderma sinistral and $B$ megastoma on the Iceland Plateau during the main phase of TII was caused by a massive meltwater event.

The appearance of the so-called "warm" Atlantic foraminifer $B$. megastoma along with atypically low benthic $\delta^{18} \mathrm{O}$ during a phase when all other planktonic data indicate cold surface water conditions seems a biogeographic contradiction. What kind of paleoceanographic conclusions may be drawn from this event? Comparing the strong decrease of $\sim 1.4 \%$ in $\delta^{18} \mathrm{O}$ records of $C$. wuellerstorfi at the onset of the Beella event with the minor change of about $0.4 \%$ in the planktonic $\delta^{18} \mathrm{O}$ records, it seems as if the surface and deep waters in both regions were decoupled during early TII (Figure 6). However, the coeval appearance of $B$. megastoma together with low benthic $\delta^{13} \mathrm{C}$ in both regions supports a direct linkage. Assuming that this synchroneity is correct, it is suggested that the Beella event and the change in the $\delta^{13} \mathrm{C} / \delta^{18} \mathrm{O}$ records of $C$. wuellerstorfi were directly or indirectly caused by the same water mass.

In previous studies [Veum et al., 1992; Fronval and Jansen, 1996; 1997; Vidal et al., 1998] it has been hypothesized that low glacial benthic $\delta^{18} \mathrm{O}$ values were caused by brines. It seems difficult, however, that brines ejected during sea ice formation can account alone for the widespread phenomenon of low benthic $\delta^{18} \mathrm{O}$ spikes observed in very different parts of the Nordic seas [Veum et al., 1992; Bauch et al., 1996; Costello and Bauch, 1997; Fronval and Jansen, 1997]. Because of the cold surface water conditions in the Nordic seas and the NE Atlantic at the time of the Beella event, we suggest that this event was caused by Atlantic water moving northward below the surface, i.e., a type of Arctic Ocean convection in which Atlantic surface water is subducted below a cold halocline. On the basis of low benthic $\delta^{18} \mathrm{O}$ and faunal evidence a similar circulation type has been also suggested for parts of the last glacial period [Rasmussen et al., 1996], a situation which might also explain the age reversals found between benthic and planktonic foraminifera during this time [Voelker et al., 1998].

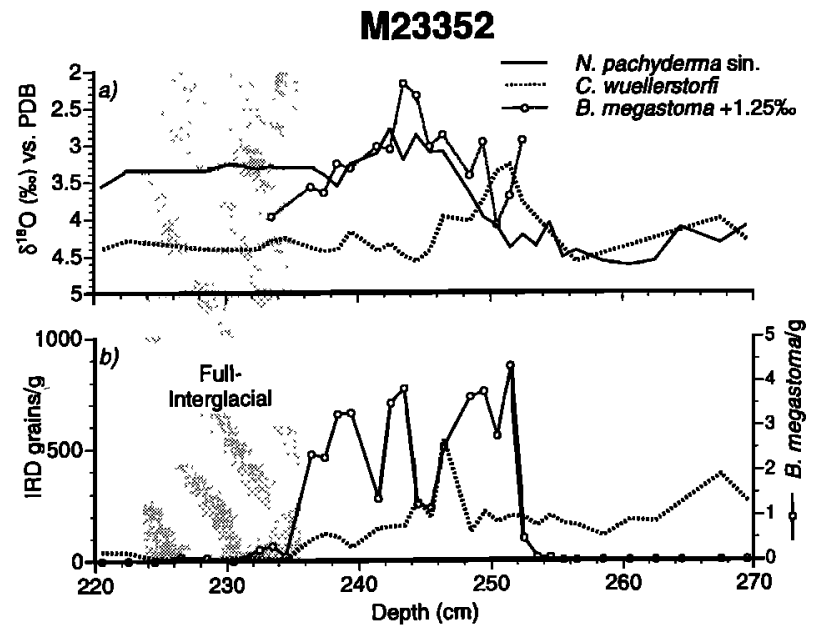

Figure 5. Oxygen isotope records from the Nordic seas compared with abundance records of Beella megastoma and IRD. A correction of $1.25 \%$ o has been applied to the original $\delta^{18} \mathrm{O}$ record of $B$. megastoma (see Figure 4). 


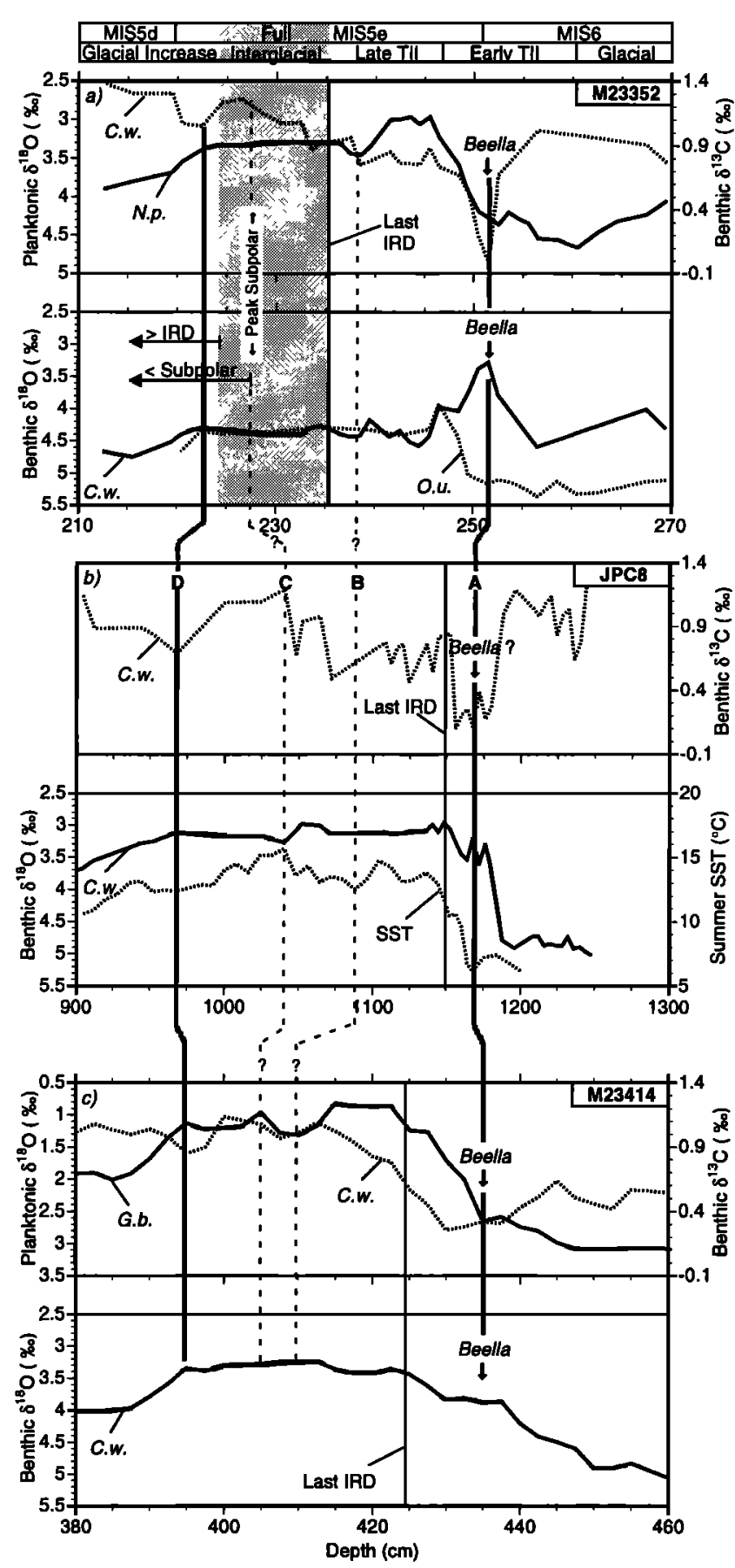

Figure 6. Paleoceanographic changes in the Nordic seas and their correlation (lines A-D) with the North Atlantic (Figures $6 b$ and $6 c$ ). The planktonic $\delta^{18} \mathrm{O}$ record in Figure $6 \mathrm{a}$ and the stable isotope records in Figure $6 \mathrm{c}$ are smoothed records of the raw data shown in Figsures 2 and 3 . The shaded area, which marks full interglacial conditions in the Nordic seas, is defined using the IRD record only. It was not correlated to M23414 because in the NE Atlantic the IRD reappeared much later (see Figure 3 ). On the basis of the 8180 and $\delta^{13} \mathrm{C}$ records a good correlation is found for the onset of the Beella event during early TII (Line A) and a good agreement is also observed for the timing of global ice volume increase after full interglacial conditions in the Nordic seas (Line D). Data of JPC8 are from Oppo et al. [1997].
Because the $\delta^{18} \mathrm{O}$ and $\delta^{13} \mathrm{C}$ records based on $C$ wuellerstorfi in cores JPC8 and M23352 both show similar values during the start of the Beella event (Figure 6), bottom water properties must have been comparable north and south of Iceland. A similar conclusion may be drawn from the relation between sea surface temperature (SST) proxies and benthic $\delta^{18} \mathrm{O}$ [see also Cortijo et al., 1994]. Oppo et al. [1997] interpreted their benthic $\delta^{13} \mathrm{C}$ depletion in early TII as the replacement by deep waters of southern origin with a low $\delta^{13} \mathrm{C}$. It is hard to believe that this deep water was entering the Nordic seas by overflowing the relatively shallow IcelandScotland Ridge. However, it seems also unlikely that this prominent $\delta^{13} \mathrm{C}$ depletion originated in the Nordic seas because of its association with the onset of the Beella event, which clearly indicates a southern origin. Besides $B$. megastoma, also the deep-living species $G$. truncatulinoides [Deuser and Ross, 1989] appeared on the Rockall Plateau relatively early in TII, corroborating the hypothesis of a northwardly flowing water mass. According to some recent studies, water mass changes in the Southern Ocean led the onset of northern deglaciation by several thousand years [e.g., Broecker and Henderson, 1998, and references therein]. Connecting our observation at intermediate depth in the NE Atlantic and the Nordic seas during early TII with water mass changes much farther south may be intriguing; however, it is still a rather speculative undertaking.

The late phase of TII is marked by significantly increased $\delta^{18} \mathrm{O}$ values in both benthic species on the Iceland Plateau (Figure 6). This change was probably induced by the onset of vertical overturning of surface waters, a process that leads to cold bottom water temperatures [Rudels, 1995]. However, there still is a certain variability noted in benthic $\delta^{18} \mathrm{O}$ on the Iceland Plateau, which together with the concurrent presence of $B$. megastoma (Figure 2), indicates that deep water formation here remained in a transient state until the end of TII, i.e., switching between an Arctic Ocean convection style and a vertical convection mode.

\subsection{Full Intergacial Conditions}

The lack of IRD, increasing abundance of subpolar foraminifera along with stable planktonic and benthic $\delta^{18} \mathrm{O}$ values document full interglacial water mass conditions on the Iceland Plateau. We interpret that during this part of MIS5e thermohaline circulation and vertical overturning of these water masses on the Iceland Plateau was finally established. Using the correlation scheme (Figure 6) the phase showing warmest SSTs on the Iceland Plateau falls into roughly the same interval in JPC 8. However, the main turning point when SSTs declined at the end of MIS5e is diachronous and is noted first on the Iceland Plateau with a steep decrease in subpolar foraminifera and the recurrence of IRD (see also data by Fronval and Jansen, [1997]). This early cooling on the Iceland Plateau already during full interglacial conditions has its counterpart in the Holocene [Bauch et al., 1996; 1999] and clearly leads the increase in the benthic $\delta^{18} \mathrm{O}$ signal caused primarily by a change in global ice volume.

\subsection{Bottom Water Temperature Gradients}

It has long been known that temperature in the deep water increased across glacial-interglacial transitions [e.g., Chappel and Shackleton, 1986]. Since the Nordic seas and the NE 
Atlantic were covered at least seasonally by low-saline surface waters as well as sea ice during the first half of TII, the lack of thermohaline surface circulation probably prevented a direct vertical water mass overturn on the Iceland Plateau and the formation of very cold bottom waters. The strong shift in benthic $\delta^{18} \mathrm{O}$ of up to $1.4 \%$ in our records during early TII is hard to reconcile with a change in global ice because an even larger shift in $\delta^{18} \mathrm{O}$ due to meltwater should have been recorded by planktonic foraminifera at these latitudes. A relatively small change of $1 \%$ in infaunal benthic $\delta^{18} \mathrm{O}$ is what has been reported from the Nordic seas for Terminations I and II [Labeyrie et al., 1987; Bauch et al., 1999]. For TI this $\sim 1 \%$ change is less than recorded by corals [Fairbanks, 1989]. Although partially affected by interoceanic water $\delta^{18} \mathrm{O}$ gradients [Labeyrie et al., 1987], a global ice volume change of $\leq 1 \%$ since the Last Glacial Maximum was also calculated from pore water $\delta^{18} \mathrm{O}$ [Schrag et al., 1996].

If the small change of $-0.5 \%$ in the benthic $\delta^{18} \mathrm{O}$ record of $O$. umbonatus more accurately reflects the real change in global ice volume until the onset of the Beella event, then the bottom water temperature at the Rockall Plateau site had increased by $-4^{\circ} \mathrm{C}$. This temperature increase may have been less if our inferred northward flow of subsurface waters was already affected by ice volume changes elsewhere [Broecker and Henderson, 1998].

On the Iceland Plateau both benthic $\delta^{18} \mathrm{O}$ records show average values of $-4.4-4.5 \%$ for the full interglacial interval of MIS5e, similar to values noted in this area from the Holocene [Costello and Bauch, 1997]. The modern temperature difference between the two areas of $\sim 4^{\circ} \mathrm{C}$ is calculated for the mid-MIS5e on the basis of benthic $\delta^{18} \mathrm{O}$ values. Using only data from $O$. umbonatus, Labeyrie et al. [1987] reconstructed bottom temperatures of $-1^{\circ} \mathrm{C}$ for the Nordic seas and the $\mathrm{N}$. Atlantic during the last two glaciation. However, despite good agreement between $\delta^{18} \mathrm{O}$ values in $O$. umbonatus and $C$. wuellerstorfi during late TII and the full interglacial, very different values are recorded by us for the glacial and early deglacial intervals. This offset between infaunal and epifaunal $\delta^{18} \mathrm{O}$ values is typical in glacial sediments from the Nordic seas [Vogelsang, 1990] and may be due to a very different environmental demand of each of the two species [Corliss, 1985; Lutze and Thiel, 1989; Linke and Lutze, 1993], i.e., the probability that both species even though from the same sample may not always have responded to the same event. Moreover, considering the relatively low time resolution in our Iceland Plateau record, we cannot fully preclude bioturbational mixing despite our applied sampling technique.

\section{Summary and Conclusions}

Water mass conditions between the Nordic seas and the NE Atlantic were investigated for the time after MIS6 and through MIS5e. During early TII the Atlantic-type planktonic foraminifera $B$. megastoma occurred in the NE Atlantic and the Nordic seas together with unusually low $\delta^{18} \mathrm{O}$ and $\delta^{13} \mathrm{C}$ values in benthic foraminifera. Although further aspects of the ecology of $B$. megastoma still need to be solved, important paleoceanographic conclusions may be drawn from these data. They indicate that water mass exchange between the NE Atlantic and the Nordic seas was active during early TII but differed from the later part of MIS5e. On the basis of a detailed event stratigraphy between the cores, the water mass history between the regions was reconstructed.

During early TII, SST proxies indicate that surface water conditions in the Nordic seas and the NE Atlantic were cold and covered with meltwater and sea ice. Such conditions greatly inhibited oceanic heat release, direct vertical overturning of water masses, and thus the formation of cold bottom water in the Nordic seas. In this time interval the onset of the Beella event is observed coeval with the steep decrease of benthic $\delta^{18} \mathrm{O}$ and $\delta^{13} \mathrm{C}$ values. To interpret these records, we suggest a type of northward advection of relatively warm and saline water masses to the NE Atlantic and the Nordic seas occurring below the cold and low-density surface waters. This inflow from the south below a stratified surface in combination with the lack of heat release to the atmosphere can explain part of the $1.4 \%$ change observed in the benthic $\delta^{18} \mathrm{O}$ records. Whether this benthic $\delta^{18} \mathrm{O}$ decrease during early TII was primarily caused by increased bottom water temperatures, a downdraw of $\delta^{18} \mathrm{O}$-depleted surface waters, global ice volume changes, and/or a complex combination of all these factors remains still an open question.

During the later part of TII, water mass advection from the NE Atlantic into the Nordic seas was variable, switching between a subsurface and a surface inflow. This variability was most likely triggered by salinity variations at the surface and continued until the end of the deglaciation when IRD deposition ceased and the increasing abundance of subpolar planktonic foraminifera heralded full interglacial conditions. This full interglacial interval was characterized in the Nordic seas by vertical water mass convection leading to cold bottom waters and a bottom water temperature difference between the Rockall and Iceland plateaus of $\sim 4^{\circ} \mathrm{C}$, which is comparable with the modern gradient.

Our detailed investigation of TII and the last interglaciation indicates that the oceanic system during glacial to interglacial change at high northern latitudes is even more complex than previously suggested. Despite considerable changes in surface water properties, thermohaline circulation and deep water formation continued, although switching between different modes. Since the prerequisite for paleoceanographic reconstructions greatly depends on the used proxy tools, this study shows that still more knowledge is required to better understand the ecological response of planktonic and benthic foraminiferal species in a changeable environment.

Acknowledgments. We thank K. Nagel and J.-M. Wolfsdorf for assistance in core sampling and sediment processing. We also very much appreciate the help of J.P. Helmke for conducting gray level measurements. We are grateful to D. Bauch and W.W. Hay for discussions and for improving the style of the manuscript. The contribution greatly benefitted from stimulating review comments by J.F. McManus and an anonymous referee.

\section{References}

Aagaard, K., and E. C Carmack, The Arctic Ocean and climate: A perspective, in The Polar Oceans and Their Role in Shaping the Global Environment, Geophys. Monogr.
Ser., vol. 85, edited by O.M. Johannesson et al., pp. 5-20, AGU, Washington, D.C., 1994.

Bauch, D., J. Carstens, and G. Wefer, Oxygen isotope composition of living Neogloboquadrina pachyderma (sinistral) in the Arctic Ocean, Earth Planet. Sci. Let. , 146, 47-58, 1997. 
Bauch, H. A., Beella megastoma (Earland) in late Pleistocene Norwegian-Greenland Sea sediments: Stratigraphy and meltwater implication, J. Foraminiferal Res. , 24, 171-177, 1994.

Bauch, H. A., Monitoring Termination II at high latitude: Anomalies in the planktic foraminiferal record, Mar. Geol, , 131, 89102,1996

Bauch, H. A., H. Erlenkeuser, P. M. Grootes, and J. Jouzel, Implications of stratigraphic and paleoclimatic records of the last interglaciation from the Nordic seas, Quat. Res. , 46, 260-269, 1996.

Bauch, H.A., H. Erlenkeuser, K. Fahl, R.F. Spielhagen, M.S. Weinelt, H. Andruleit, and R. Henrich, Evidence for a steeper Eemian than Holocene sea surface temperature gradient between Arctic and sub-Arctic regions, Palaeogeog. Palaeoclimatol., Palaeoecol., 145 (1-3), 95-117, 1999.

Bé, A. W., and D. S. Tolderlund, Distribution and ecology of living planktonic foraminifera in surface waters of the Atlantic and Indian Oceans, in The Micropaleontology of the Oceans, edited by B. M. Funnel, and W. R. Riedel, pp. 105-149, Cambridge Univ. Press, New York, 1971.

Belanger, P. E., Paleo-oceanography of the Norwegian-Sea during the past 130.000 years: Coccolithophorid and foraminiferal data, Boreas, 11, 29-36, 1982.

Bond, G. et al., Evidence for massive discharges of icebergs into the North Atlantic ocean during the last glacial period, Nature, 360, 245-249, 1992.

Broecker, W. S., and G. H. Denton, The role of ocean-atmosphere reorganizations in glacial cycles, Geochim. et Cosmochim. Acta, 53, 2465-2501, 1989.

Broecker, W. S., and G. M. Henderson, The sequence of events surrounding Termination II and their implications for the cause of glacial-interglacial $\mathrm{CO}_{2}$ changes, Paleoceanography, 13, 352-364, 1998.

Carstens, J., Verteilung planktischer Foraminiferen in der Wassersaule, in The Expedition ARKTISVIVI of RV Polarstern in 1990, edited by J. Thiede and G. Hempel, pp. 60-62, Alfred Wegener Inst. for Polar und Meeresforsch., Bremerhaven, Germany, 1991.

Carstens, J., and G. Wefer, Recent distribution of planktonic foraminifera in the Nansen Basin, Arctic Ocean, Deep Sea Res., Part A, 39 (2), 507-524, 1992.

Carstens, J., D. Hebbeln, and G. Wefer, Distribution of planktic foraminifera at the ice margin in the Arctic (Fram Strait), Mar. Micropal., 29, 257-269, 1997.

Chappel, J., and N. J. Shackleton, Oxygen isotopes and sea level, Nature, 324, 137 140, 1986

Corliss, B. H., Microhabitats of benthic foraminifera within deep-sea sediments, Nature, 314, 435-438, 1985.

Cortijo, E., Duplessy, J.-C., Labeyrie, L., Leclaire, H., Duprat, J., and van Weering, T. C. E., Eemian cooling in the Norwegian Sea and North Atlantic ocean preceding continental ice-sheet growth, Nature, 372, 446-449, 1994.

Cortijo, E., P. Yiou, L. Labeyrie, and $M$.
Cremer, Sedimentary record of rapid climatic variability in the North Atlantic Ocean during the last glacial cycle, Paleoceanography, lO(5), 911-926, 1995.

Costello, O. P., and H. A. Bauch, Late Pleistocene-Holocene productivity record of benthic foraminifera from the Iceland Plateau (Core PS1246-2), in Contributions to the Micropaleontology and Pale-oceanography of the Northern North Atlantic, edited by $\mathrm{H}$. C. Hass and M. A Kaminski, pp. 141-148, Grzybrowski Found. Spec. Publ. 5, Kracow 1997.

Crowley, T. J., and K. Y. Kim, Milankovitch forcing of the last interglacial sea level, Science, 265, 1566-1568, 1994.

Deuser, W. G., and E. H. Ross, Seasonally abundant planktonic foraminifera of the Sargosso Sea: Succession, deep-water fluxes, isotopic compositions, and paleoceanographic implications, $J$. Foraminiferal Res., 19(4), 268-293, 1989.

Duplessy, J. C., L. Labeyrie, and P. L. Blanc, Norwegian Sea Deep Water variations over the last climatic cycle: Paleooceanographical implications, in: Long and short term variability of climate edited by Wanner, $H$. and $U$. Siegenthaler : pp. 83-116, Springer-Verlag, 1988

Duplessy, J. C., L. Labeyrie, A. Juillet, F. Maitre, J. Duprat, and M. Sarnthein, Surface salinity reconstruction of the North Atlantic Ocean during the last glacial maximum, Ocean. Acta, 14,311324, 1991.

Fairbanks, R. G., A 17,000-year glacioeustatic sea level record: influence of glacial melting rates on the Younger Dryas event and deep ocean circulation, Nature, 342, 637-642, 1989.

Fronval, T., and E. Jansen, Rapid changes in ocean circulation and heat flux in the Nordic seas during the last interglacial period, Nature, 383, 806-810, 1996.

Fronval, T., and E. Jansen, Eemian and early Weichselian (140-60 ka) paleoceanography and paleoclimate in the Nordic seas with comparisons to Holocene conditions, Paleoceanography, 12(3), 443-462, 1997.

Hemleben, C., M. Spindler, and O. R. Anderson, Modern Planktonic Foraminifera, 363 pp., Springer-Verlag, New York, 1989.

Henrich, R., Dynamics of atlantic water advection to the Norwegian-Greenland Sea-- a time-slice record of carbonate distribution in the last $300 \mathrm{ky}, \mathrm{Mar}$. Geol., 145, 95-131, 1998.

Johannessen, T., E. Jansen, A. Flatøy, and A. Ravelo, The relationship between surface water masses, oceanographic fronts and paleoclimatic proxies in surface sediments of the Greenland, Iceland, Norwegian Seas, in Carbon Cycling in the Glacial Ocean: Constraints of the Oceans!'s Role in Global Change, edited by R. Zahn et al., pp. 61-85, Springer-Verlag, New York, 1994.

Kellogg, T. B., Paleoclimatic significance of subpolar foraminifera in high-latitude marine sediments, Can. J. Earth Sci., 2l, 189-193, 1984.
Kipp, N. G., New transfer function for estimating past sea-surface conditions from sea-bed distribution of planktonic foraminiferal assemblages in the North Atlantic, Geol. Soc. Mem., 145, 3-41, 1976.

Labeyrie, L. D., J. C. Duplessy, and P. L. Blanc, Variations in mode of formation and temperature of oceanic deep water over the past 125,000 years, Nature, 327, 477-482, 1987.

Labeyrie, L., et al., Surface and deep hydrology of the northern Atlantic ocean during the past 150000 years, Philos. Trans. R. Soc. London, Ser. B, 348, 255 264, 1995.

Lehman, S. L., and L. D. Keigwin, Sudden changes in North Atlantic circulation during the last deglaciaton, Nature, 356, 757-762, 1992.

Linke, P., and G. F. Lutze, Microhabitats preference of benthic foraminifera - A static concept or a dynamic adaptation to optimize food acquisition?, Mar. Micropal., 20, 215-234, 1993.

Lutze, G. F., and H. Thiel, Epibenthic foraminifera from elevated microhabitats: Cibicidoides wuellerstorfi and Planulina ariminensis, J. Foraminiferal Res., 19, 153$158,1989$.

Martinson, D. G., N. G. Pisias, J. D. Hays, J. Imbrie, T. C. Moore, and N. J. Shackleton, Age dating and the orbital theory of the Ice Ages: Development of a highresolution 0 to 300,000 years chronostratigraphy, Quat. Res., 27, 1-29, 1987.

McManus, J., G. Bond, W. Broecker, S. Johnsen, L. Labeyrie, and S. Higgins, High-resolution climate records from the North Atlantic during the last interglacial, Nature, 37I, 326-329, 1994.

Oppo, D. W., and S. J. Lehman, Suborbital timescale variability of North Atlantic Deep Water during the past 200,000 years, Paleoceanography, 10, 901-910, 1995.

Oppo, D. W., M. Horowitz, and S. J. Lehman, Marine core evidence for reduced deep water production during Termination II followed by a relatively stable substage 5e (Eemian), Paleoceanography, 12, 5163, 1997.

Rahmstorf, S., Bifurcations of the Atlantic thermohaline circulation in response to changes in the hydrological cycle, Nature, 378, 145-149, 1995.

Rasmussen, T. L., E. Thomsen, T. C. E. van Weering, and L. Labeyrie, Rapid changes in surface and deep waters at the Faeroe Margin during the last 58,000 years, Paleoceanography, 11, 757-771, 1996.

Ruddiman, W. F., and A. McIntyre, The North Atlantic Ocean during the last deglaciation, Palaeogeog. Palaeoclimatol. Palaeoecol., 35 (2-4), 145-214, 1981.

Ruddiman, W. F., B. Molfino, A. Esmay, and E. Pnkras,- Evidence hearing on the mechanism of rapid deglaciation, Clim. Change, 3, 65-87, 1980.

Rudels, B., The thermohaline circulation of the Arctic and the Greenland seas, Philos. Trans. R. Soc. London, Ser. B,, 352, 1-13, 1995.

Sarnthein, M., and R. Tiedemann, Younger 
Dryas-style cooling events at glacial Terminations I-VI at ODP-Site 658: associated benthic $\delta^{13} \mathrm{C}$ anomalies constrain meltwater hypothesis, Paleoceanography, 5, 1041-1055, 1990.

Sarnthein, M., K. Winn, S. J. A. Jung, J. C. Duplessy, L. Labeyrie, H. Erlenkeuser, and G. Ganssen, Changes in east Atlantic deepwater circulation over the last 30.000 years: Eight time slice reconstructions, Paleoceanography, 9, 209-267, 1994.

Sarnthein, M., et al., Variations in Atlantic surface ocean paleoceanography, $50^{\circ}$ $80^{\circ} \mathrm{N}$ : A time-slice record of the last 30,000 years, Paleoceanography, 10, 1063-1094, 1995.

Schrag, D. P., G. Hampt, and D. W. Murray, Pore fluid constraints on the temperature and oxygen isotopic composition of the glacial ocean, Science, 272, 1930-1932, 1996.

Spielhagen, R.F., and H. Erlenkeuser, Stable oxygen and carbon isotopes in planktic foraminifers from Arctic Ocean surface sediments: Reflection of the low salinity surface water layer, Mar. Geol., 119, 227. $250,1994$.

Stoner, J. S., J. E. T. Channell, and C. Hillaire-Marcel, Magnetic properties of deep-sea sediments off southwest Greenland: Evidence for major differences between the last two deglaciations, Geology, 23(3), 241-244, 1995.

Swift, J., The Arctic Waters, in The Nordic Seas, edited by B. Hurdle, pp. 129-151, Springer-Verlag, New York, 1986.

Veum, T., E. Jansen, M. Arnold, I. Beyer, and J. C. Duplessy, Water mass exchange between the North Atlantic and the Norwegian Sea during the past 28,000 years, Nature, 356, 783-785, 1992.

Vidal, L., L. Labeyrie, and T.C.E. van Weering, Benthic $\delta^{18} 0$ records in the North Atlantic over the last glacial period (60-10 kyr): Eviodence for brine formation, Paleoceanography, 13, 245251, 1998.

Voelker, A. H. L., M. Sarnthein, P. M. Grootes, H. Erlenkeuser, C. Laj, M. J. Nadeau, and M. Schleicher, Correlation of marine ${ }^{14} \mathrm{C}$ ages from the nordic seas with the GISP2 isotope record: implications for radiocarbon calibration beyond $25 \mathrm{ka} B P$, Radiocarbon, 4O(1), 517-534, 1998.

Vogelsang, E., Paläo-Ozeanographie des Europäischen Nordmeeres anhand stabiler Kohlenstoff- und Sauerstoffisotope, Rep. $S F B 313,23$, pp. 1-136, Kiel Univ., Kiel, 1990.

H.A. Bauch, GEOMAR Research Center for Marine Geosciences, Wischhofstrasse 1-3, 24148 Kiel, Germany. (hbauch@geomar.de)

H. Erlenkeuser, Leibniz Laboratory, Kiel University, Max-Eyth-Strasse 11, $24098 \mathrm{Kiel}$, Germany. (herlenkeuser@leibniz.uni-kiel.de)

S.J.A. Jung, Institute of Earth Sciences, Amsterdam Free University, 1081 HV Amsterdam, The Netherlands. (jung@geo.vu.nl)

J. Thiede, Alfred-Wegener-Institute for Polar and Marine Research, Columbusstrasse, 27568 Bremerhaven, Germany. (jthiede@awibremerhaven.de)

(Received November 2, 1998; revised October 4, 1999;

accepted October $7,1999$. 